JOURNAL OF SECURITY AND SUSTAINABILITY ISSUES

ISSN 2029-7017 print/ISSN 2029-7025 online

2019 June Volume 8 Number 4

http://doi.org/10.9770/jssi.2019.8.4(4)

Scopus

\title{
ECONOMIC POLICY FOR SUSTAINABLE REGIONAL DEVELOPMENT: A CASE STUDY OF SLOVAK REPUBLIC
}

\author{
František Vojtech ${ }^{1}$, Michal Levický2 ${ }^{2}$, Stanislav Filip ${ }^{3}$ \\ ${ }^{1,3}$ School of Economics and Management in Public Administration in Bratislava, Slovak Republik \\ ${ }^{2}$ Constantine the Philosopher University in Nitra, Slovak Republik
}

E-mails:1frantisek.vojtech@vsemvs.sk; ${ }^{2 m l e v i c k y @ g m a i l . c o m ; ~}{ }^{3}$ staislav.filip@vsemvs.sk

Received 11 January 2018; accepted 15 December 2018; published 30 March 2019

\begin{abstract}
Authors of the article focus on the current issues regarding foreign direct investments and their impact on the economic development of Slovak regions. The aim of this article is to draft overview of stage of current development within the economic and investment policy of the Government of the Slovak Republic to meet the needs of regional development. The introduction part presents the theoretical basis described by local and foreign authors reflecting the level of foreign direct investments use including their influence on the economic progress in particular regions emphasised on the development and promotion of small and medium-sized enterprises. Analysis of the government investment policy is carried out in the specification part underlining the significant role of the Slovak Investment and Trade Development Agency. Stated knowledge provide the theoretical framework for the experimental part of the article. Experimental part of the article by the means of numerical statistics and comparison method analyses and evaluates the level of investment support provided to small and medium-sized regional enterprises through projects sustained by the Slovak Investment and Trade Development Agency within the years 2012 and 2017.Successfully concluded projects concerning the foreign investment aid for the particular Slovak regions are analysed in experimental part, which also quantifies investments based on their contribution to the growth in jobs and provides an overview of the cooperating activities among regions of Slovakia from 2007 to 2017. Contributional outcome of the experimental part of the article is presentation of governmental standards, which are required from regions in order to obtain investment aid while job creation is taken into account. Issued conclusions may inspire further economic operators and authorities responsible in area of social and economic regional development in Slovak republic, regions of other Member States and third countries of Europe as well.
\end{abstract}

Keywords: economic policy; small and medium-sized enterprises; state; science and technology; investment, project

Reference to this paper should be made as follows: Vojtech, F..; Levický, M., Filip, S. 2019. Economic policy for sustainable regional development: a case study of Slovak Republic, Journal of Security and Sustainability Issues 8(4): 597-608.

http://doi.org/10.9770/jssi.2019.8.4(4)

JEL Classifications: M31

\section{Introduction}

Sustainable development of a country is driven by many factors (e.g. Eddelani, O.; El Idrissi, N. E.; Monni, S. (2019); Zeibote, Z.; Volkova, T.; Todorov, K. (2019); Batkovskiy, A.M., Leonov, A.V., Pronin, A.Yu., Semenova, E.G., Fomina, A.V., Balashov, V.M. (2019); Petrenko, Y., Vechkinzova, E., Antonov, V. (2019)), among which investments paly one the most important role. Several definitions of investment can be found in professional and scientific literature. Among the most commonly used are the definitions provided by the United Nations Organization or, for example, by the U.S. Department of Commerce. Most authors agree on the definition, that investment regards as a form of long-term international capital movement. For example, Lipková (2002) describes this definition. If we were to deal with when foreign investment became more important, we could say it was only in the last decades of the 20th century. The authors' particular theories focus on the reasons for companies investing abroad. These reasons can be labeled as $5 \mathrm{~W}$. Who is an investor? What kind of investment 
is it? Why does an enterprise invest abroad? Where will the investment be realized? When does the company decide to invest abroad? How does the company enter the foreign market? This view can be found in the publications by Lipková (2002) and Vaysilova (2016). The issue of foreign investment is also related to the concept of foreign trade or foreign trade policy. Baláž (2001) argues that the philosophy lies in the fact that the modern economic policy in the whole of its complex is focused mainly on the support of structural changes in favor of the most prosperous professions and types of production, high technologies and services. From the available knowledge, we can assume that foreign trade has recently dominated the factors affecting economic growth. Tourism as a specific impact affecting economic growth of the Slovak Repubic and other countries (Panfiluk, E.; Szymańska, E. (2017); Filip, S. Filipová, L Stehlíková, B. (2019)). Associated problem with solved issue economic effects of dynamics in migration processes solve Melnyk, T. and Losheniuk, O. (2018), Lialina, A. (2019).

\section{The current state}

\subsection{Effects and conditions of foreign investment}

In connection with the effects of foreign direct investment, it is possible to meet the views of many authors. What benefits do proponents expect a country to reap from foreign direct investment inflows? Because it embodies technology and know-how as well as foreign capital, foreign direct investment can benefit host economies through knowledge spillovers as well as linkages between foreign and domestic firms. Potential positive effects include productivity gains, technology transfer, exposure of domestic firms to new processes, managerial skills and know-how, enhancements to employee training, development of international production networks, and broader access to markets (Tvaronavičienė, M., Černevičiūtė, J. 2015). Alfaro, L. and Johnson, M.S. (2013) present that when new products or processes are introduced to the domestic market by foreign firms, domestic firms may benefit from the accelerated diffusion of new technology. In some cases, this might occur simply by domestic firms observing foreign firms, and in other cases through labor turnover as domestic employees hired by foreign firms move to domestic firms. These benefits, together with direct capital financing, suggest an important role for foreign direct investment in modernizing national economies and promoting economic development. Fabus, M. (2014) argue that acquisition of new foreign direct investment and maintaining existing foreign investors is becoming an important part of a policy aimed at the competitiveness of national economy increasing. When it comes to getting key foreign investors, a country able to attract more investors will win a particularly strong inter-state competition and achieve intense multiplier effect of foreign direct investment for the whole economy. Dilek T., Aytaç G. and Mukhtar S. Abubakar (2015) emphasize that Foreign Direct Investment has been affecting global business affairs for decades. A country, whether developed or developing, necessitates more foreign direct investment entry than other countries because the foreign direct investment inflow may bring certain advantages such as capital accumulation, knowledge, know-how transfer, and obtainment of updated technology. Thus, the entry of foreign direct investment into a host country is expected to reveal positive aftermaths. This also confirmed Kais, S. (2018). His error correction model confirms the existence of a double causal relationship between foreign direct investment and GDP growth, and between financial development and foreign direct investment and between GDP growth and financial development. The effects of foreign direct investment in Slovakia were evaluated by Fabus, M. (2015). The author writes, that foreign direct investment was an important factor which ensured to Slovakia greater competitiveness, as it has introduced new technologies, created jobs, brought know-how as well as managerial and entrepreneurial culture.

In order for foreign direct investment to bring the expected effect to the beneficiary's country, certain conditions must be met (Shuyan, L., Fabuš, M. (2019)). The results of the authors Borensztein, E., De Gregorio, J. and Lee, J.-W. (1998) suggest that foreign direct investment is an important vehicle for the transfer of technology, contributing relatively more to growth than domestic investment. However, the higher productivity of foreign direct investment holds only when the host country has a minimum threshold stock of human capital. Thus, foreign direct investment contributes to economic growth only when a sufficient absorptive capability of the advanced technologies is available in the host economy. The importance of economic freedom for the effects of foreign direct investment is emphasized by many authors. For example, W.N.W.Azman-Saini, Ahmad 
Zubaidi Baharumshah and Siong Hook Law (2010) reveal that foreign direct investment by itself has no direct (positive) effect on output growth. Instead, the effect of foreign direct investment is contingent on the level of economic freedom in the host countries. This means the countries promote greater freedom of economic activities gain significantly from the presence of multinational corporations. Their results are supported by Ghazalian, P.L (2019), which emphasizes positive effects of economic freedom on foreign direct investment inflows. Author reveals that economic freedom sub-components have varying impacts on foreign direct investment inflows, where rule of law, market openness, and less-restrictive regulatory environment stand out as the major FDI-promoting institutional factors. Sajid Anwar and Lan Phi Nguyen (2010) on the example of Vietnam's economy suggest that the impact of foreign direct investment on economic growth in Vietnam will be larger if more resources are invested in education and training, financial market development and in reducing the technology gap between the foreign and local firms. Bénassy-Quéré, A., Coupet, M., Mayer, T. (2007) evaluate whether the similarity of institutions between the host and the origin country raises bilateral foreign direct investment. Authors find that a wide range of institutions, including bureaucracy, corruption, but also information, banking sector and legal institutions, do matter for inward foreign direct investment independently of GDP per capita. Interestingly, weak capital concentration and strong employment protection tend to reduce inward foreign direct investment. Institutional proximity between the origin and the host country also matters, but we find little impact of institutions in the origin country. These results are encouraging in the sense that efforts towards raising the quality of institutions and making them converge towards those of source countries may help developing countries to receive more foreign direct investment, independently of the indirect impact of higher GDP per capita. Corruption as a specific problem and its importance within macroeconomy in realtion with foreign direct investment analyse Siller, H. and Cibák, L' (2016).

\subsection{Slovakia's government policy on investment}

If any government wants the regions to grow economically equally, they need to create adequate conditions for them (Mayorova, A.N.; Panasenko, S.V.; Nikishin, A.F.; Ivanov, G.G.; Mayorova, E.A. (2018); Pavolová, H.; Bakalár, T.; Emhemed, E.M.A, Hajduová, Z.; Pafčo, M. (2019). First of all, it is about legislative action and the implementation of practical arrangement. Slovak government in the document The government program for 2016 - 2020 approved the economic policy priorities that followed The government program for yeras 2012 2016. The government has set itself the goal of pursuing an economic policy consisting of sectoral and crosscutting policies as the main instrument to support the development of the real economy. The priority is to ensure coherence mechanisms so that the various components of economic policy correspond, interconnect and create the greatest possible synergy. The basic roles of the various components of economic policy are to shape the growth potential of the national economy. (Government Program Statement for 2012 - 2016 and 2016 - 2020)

If we focus on the area of investment, we must mention the government's priority in this area. In the field of activation of investment activity it is stated, that the government will create conditions for a favorable investment climate for domestic and foreign investors. The Law on Investment Aid propose reducing the minimum investment amount and at the same time assess the risk of harming domestic producers. In an inflow of foreign investments, economic policy will focus primarily on supporting established investors in expanding their activities in the Slovak Republic through post-investment care and their stronger entry into industrial research and development in Slovakia. (Government Program Statement for 2012 - 2016 and 2016 - 2020)

If we compare these government priorities with the priorities set by it in the current programming period, it can be said that they are continuously linked to the previous period and shifted to the future. In particular, we can state that the government determines the basic contours of the prospective direction of the economy in the medium and long term by adopting the strategy economic policy. (Government Program Statement for 2016 2020, The law on regional investment aid)

If we look at this program in more detail, we see that the government is also reacting to the economic developments in the world. It is necessary in the SR to fully develop the principles and culture of the new level of production relations called INDUSTRY 4.0. The already agreed Strategy for Research and Innovation for 
Smart Specialization is already the starting point. (Government Program Statement for 2016 - 2020, Government regulation of investment aid)

At the same time, the government's program lists specific practical implementers of this part of the program. SARIO (Slovak Investment and Trade Development Agency), as an organization of the Ministry of Economy of the Slovak Republic, according to the economic policy strategy, flexibly seeks investment opportunities for domestic and foreign entrepreneurs, carries out appropriate investment care in order to dynamize the export possibilities of the Slovak economy, creating conditions for employment growth.

\section{Experimental part}

\subsection{Investment support in regions through investment projects}

One of the leading organizations involved in the acquisition of foreign investments and the support of export activities of Slovak companies is the state agency SARIO under the authority of the Ministry of Economy of the Slovak Republic.

The agency provides a broad portfolio of services to home and foreign investors. The Agency's activities to support the inflow of investment and expansion projects of established companies stimulate not only the quantitative but also the qualitative growth of the economy. The surge in value-added investments using the latest technology is currently one of the positive trends reflecting the Agency's performance. (Government Program Statement for 2012 - 2016, Annual report SARIO 2017)

On the other side, increasing the competitiveness of Slovak entities and supporting their transformation into efficient and successful entities in a globalized world market is supported by SARIO's pro-export activities and platforms that shift the focus of export from goods towards exports of services or investments. The Slovak Investment and Trade Development Agency can judge the year 2017 as extremely successful. In terms of number of projects and creation of new jobs, it is the best results for the last 5 years. An overview of the number of completed projects, including the amount of investment and the impact on jobs, is shown in Table 1.

Table 1. Development of the numbers of completed investment projects

\begin{tabular}{|c|c|c|c|c|c|c|c|}
\hline \multicolumn{2}{|c|}{} & 2012 & 2013 & 2014 & 2015 & 2016 & 2017 \\
\hline number of completed projects & 16 & 18 & 25 & 23 & 29 & 33 \\
\hline $\begin{array}{c}\text { impact of } \\
\text { completed } \\
\text { projects }\end{array}$ & $\begin{array}{c}\text { the amount of } \\
\text { the investment }\end{array}$ & $€ 466$ million & $€ 442$ million & $€ 170$ million & $\begin{array}{c}€ 1,740 \\
\text { million }\end{array}$ & $€ 930$ million & $€ 492$ million \\
\hline
\end{tabular}

Source: Annual report SARIO 2017

It is clear from Table 1 that during the year 2017 were 33 investment projects closed, the realization of which has the potential to create almost 9,000 new direct jobs and the total investment should reach 492 million $€$. In 17 cases it was the establishment of new plants, in 16 cases the expansion projects of established companies. The arrival of higher value-added investments such as R\&D centers (1 completed project), service centers (6 completed projects) and 3 industrial production projects whose implementation also includes research and development activities can be positively evaluated. Compared to previous years, the number of such projects is increasing both in absolute terms and in relative terms.

Based on the data in Table 2 we can state that the most attractive for investors is west of Slovakia. The reasons are clear. High-skilled workforce, highway availability and high-quality infrastructure. If we want to make the other areas for investors more attractive, we have to create conditions similar to those in Western Slovakia and in other regions. 
Table 2. Distribution of implemented projects by regions in year 2017

\begin{tabular}{|c|c|c|c|c|c|c|c|c|}
\hline & $\begin{array}{l}\text { Bratislava } \\
\text { region }\end{array}$ & $\begin{array}{l}\text { Trnava } \\
\text { region }\end{array}$ & $\begin{array}{l}\text { Trencin } \\
\text { region }\end{array}$ & $\begin{array}{l}\text { Nitra } \\
\text { region }\end{array}$ & $\begin{array}{l}\text { Banska } \\
\text { Bystrica } \\
\text { region }\end{array}$ & $\begin{array}{l}\text { Zilina } \\
\text { region }\end{array}$ & $\begin{array}{l}\text { Presov } \\
\text { region }\end{array}$ & $\begin{array}{l}\text { Kosice } \\
\text { region }\end{array}$ \\
\hline \multirow{3}{*}{$\begin{array}{l}\text { number of completed projects } \\
\text { (of which the share of the total } \\
\text { number) }\end{array}$} & $\begin{array}{c}2 \\
(6 \%) \\
\end{array}$ & $\begin{array}{c}4 \\
(12 \%) \\
\end{array}$ & $\begin{array}{c}6 \\
(18 \%) \\
\end{array}$ & $\begin{array}{c}8 \\
(24 \%) \\
\end{array}$ & $\begin{array}{c}6 \\
(18 \%) \\
\end{array}$ & $\begin{array}{c}2 \\
(6 \%) \\
\end{array}$ & $\begin{array}{c}3 \\
(9 \%) \\
\end{array}$ & $\begin{array}{c}2 \\
(6 \%) \\
\end{array}$ \\
\hline & \multicolumn{4}{|c|}{ west of the SR } & \multicolumn{2}{|c|}{ middle of the SR } & \multicolumn{2}{|c|}{ east of the SR } \\
\hline & \multicolumn{4}{|c|}{$20(60 \%)$} & \multicolumn{2}{|c|}{$8(24 \%)$} & \multicolumn{2}{|c|}{$5(15 \%)$} \\
\hline \multirow{3}{*}{$\begin{array}{l}\text { value of investments in } € \\
\text { million (of which share } \\
\text { in total) }\end{array}$} & $\begin{array}{c}0.8 \\
(0.1 \%)\end{array}$ & $\begin{array}{l}117.5 \\
(24 \%)\end{array}$ & $\begin{array}{c}125.2 \\
(25 \%)\end{array}$ & $\begin{array}{c}67.3 \\
(14 \%) \\
\end{array}$ & $\begin{array}{l}37.9 \\
(8 \%)\end{array}$ & $\begin{array}{c}37.5 \\
(8 \%)\end{array}$ & $\begin{array}{c}85.3 \\
(17 \%)\end{array}$ & $\begin{array}{c}20.5 \\
(4 \%)\end{array}$ \\
\hline & \multicolumn{4}{|c|}{ west of the SR } & \multicolumn{2}{|c|}{ middle of the SR } & \multicolumn{2}{|c|}{ east of the SR } \\
\hline & \multicolumn{4}{|c|}{$310.8(63 \%)$} & \multicolumn{2}{|c|}{$75.4(15 \%)$} & \multicolumn{2}{|c|}{$105.8(21 \%)$} \\
\hline \multirow{3}{*}{$\begin{array}{l}\text { number of new jobs (of which } \\
\text { share of the total number) }\end{array}$} & $\begin{array}{c}140 \\
(2 \%)\end{array}$ & $\begin{array}{c}4,039 \\
(45 \%) \\
\end{array}$ & $\begin{array}{c}1,217 \\
(14 \%)\end{array}$ & $\begin{array}{c}1,460 \\
(16 \%) \\
\end{array}$ & $\begin{array}{l}750 \\
(8 \%) \\
\end{array}$ & $\begin{array}{c}550 \\
(6 \%) \\
\end{array}$ & $\begin{array}{c}680 \\
(8 \%) \\
\end{array}$ & $\begin{array}{c}120 \\
(1 \%) \\
\end{array}$ \\
\hline & \multicolumn{4}{|c|}{ west of the SR } & \multicolumn{2}{|c|}{ middle of the SR } & \multicolumn{2}{|c|}{ east of the SR } \\
\hline & \multicolumn{4}{|c|}{$6,856(76 \%)$} & \multicolumn{2}{|c|}{$1,300(14 \%)$} & \multicolumn{2}{|c|}{$800(9 \%)$} \\
\hline
\end{tabular}

Source: Annual report SARIO 2017

Looking at the table of closed investment projects (Table 3), it is clear that cooperation with a wide range of investment countries is evident. Significant business cooperation with Germany confirms 8 closed projects. The five projects are followed by the USA and four Japan. The most significant projects for the period include the Amazon project. The American company Amazon has opened its largest center of reverse logistics in Slovakia. The world's largest e-shop was created in July 1994, founded by Jeff Bezos. His logistics network has expanded to another point in Europe - Slovakia. The new logistics center is located in the Mountpark Sered area on an area of over 60,000 square meters. Amazon has employed around a thousand people at Sered new logistics center. Amazon's investment is not directed either to industrial production or to the automotive industry, contributing to a better distribution of investment in Slovakia. Important is its value added Amazon plans to deploy the latest technology to the reversing center. The company could be one of the first to benefit from a statewide worklife support program over a certain distance. Amazon has not made any investment aid from the state budget. Support for the establishment of the industrial park was given only by city Sered.

The real attractiveness of the Slovak business environment can also be assessed by monitoring the number of projects under development. As of 31 December 2017, SARIO had registered and developed 76 investment projects, with a total volume of almost $€ 4.2$ billion and with the potential to create more than 31000 new jobs. Compared to the same period last year, this is an increase in all indicators. The 76 projects completed by SARIO are 10 large-scale projects (over $€ 100$ million), which have a much larger potential for regional development. SARIO seeks to direct such investors primarily to the regions of Central and Eastern Slovakia. There are also 9 high added value projects - R\&D centers, service centers and industrial production with research and development activities. 37 investment projects, for which investors are also considering the districts of eastern Slovakia, the sum of investments can reach up to $€ 2.56$ billion. with the potential to create 16580 new jobs. Finally, 37 investment projects, which, among other things, are considering localization in one of the least developed districts, these investments at a flat rate of $€ 1$ billion. The euro has the potential to create some 11 813 new jobs.

Table 3. Successfully closed investment projects in 2017

\begin{tabular}{|l|c|l|c|}
\hline \multicolumn{1}{|c|}{ Company name } & Country & \multicolumn{1}{|c|}{ Description of economic activity } & $\begin{array}{c}\text { Region of the Slovak } \\
\text { Republic }\end{array}$ \\
\hline IBM Slovensko & USA & Software Development Center & Banska Bystrica \\
\hline Rochling & Germany & Production of autocomponents & Kocovce \\
\hline Versaco & Poland & Production of covers for wheels & Hnusta \\
\hline Hyca & SR & Production of trailers & Hnusta \\
\hline
\end{tabular}




\begin{tabular}{|c|c|c|c|}
\hline SPINEA & SR & Production of special bearings & Haniska pri Presove \\
\hline UNIQA Group Service Center & Austria & Managing Insurance Contracts & Nitra \\
\hline MAHLE Engine Components & Germany & Production and surface treatment of bearings & Dolny Kubin \\
\hline Amazon & USA & Distribution center of returned and non-delivered goods & Sered \\
\hline WE Trade & Ukraine & Production and processing of poultry meat & Horne Saliby \\
\hline Felss Rotaform & Germany & Production of metal shafts & Ilava \\
\hline Thorma & SR & Manufacture of metal rods & Filakovo \\
\hline Hitachi & Japan & $\begin{array}{l}\text { Design office for an electrical design for biomass } \\
\text { processing }\end{array}$ & Levice \\
\hline Danfoss Power Solutions & Denmark & Research of hydraolic components & Povazska Bystrica \\
\hline Gerhardt Braun & Germany & Manufacture of structures for the construction industry & Bratislava \\
\hline Brose & Germany & Manufacture of electric motors & Bojnice \\
\hline Strähle+Hess & Germany & Manufacture of special textiles & Topolcany \\
\hline Diebold Nixdorf & USA & IT services for financial institutions & Presov \\
\hline GMC Software Technology & Switzerland & IT services for financial institutions & Koseice \\
\hline Tata Consultancy Services & India & IT services for Jaguar Land Rover & Bratislava \\
\hline C\&A & Belgium & Distribution Center & Trnava \\
\hline Seoyon E-HWA & South Korea & Production of interior and exterior parts & Cadca \\
\hline SCA Hygiene Products & Sweden & Production of women's hygiene needs & Gemerska Horka \\
\hline Mata Automotive & Turkey & Manufacture of car components & Velky Krtis \\
\hline AWU Precision & Germany & Manufacture of cylinders and rollers & Presov \\
\hline Bauer Gear Motor & USA & Manufacture of transmissions to electric motors & Zlate Moravce \\
\hline Kasai Kopgyo & Japan & Production of interior wooden panels & Levice \\
\hline Magna Slovteca & Canada & Production of rear-view mirrors & $\begin{array}{l}\text { Nove Mesto nad } \\
\text { Vahom }\end{array}$ \\
\hline Kongsberg Automotive & Norway & Production of manual gearboxes & Vrable \\
\hline G-Tem & Japan/UK & Manufacture of pressed metal parts & Nitra \\
\hline AAF Daikin & Japan & Manufacture of air filters & Trencin \\
\hline LEAR & USA & Production of seats & Voderady \\
\hline $\mathrm{ZF}$ & Germany & Production of propulsion system & Komarno \\
\hline Punch & Belgium & Production of aluminum components & Detva \\
\hline
\end{tabular}

Source: Annual report SARIO 2017

Table 4 shows the development of the number of semifinished investment projects. How the breakdown of projects by sectors is indicated by the priority and direction of the development of our industry. He clearly leads the production of components for the automotive industry. There are 27 projects under development, which is $36 \%$ of the total project volume. Following is the engineering production with 14 projects. Interesting centers of service, including R\&D and IT centers with 6 projects. The electrical industry is also represented by 6 projects. It follows food with 5 and healthcare with 4 projects. The woodworking has 3 . The other 11 projects are included in the area other. They include building materials, the glass industry, rubber and plastics. Investors from Germany, the USA, Slovakia, Italy, Switzerland, Belgium, South Korea, Austria, the United Kingdom and Japan show the greatest interest.

What is it difficult and strenuous to convince an investor to invest in our country, we see the proportion of projects under way and realized projects. We can compare 76 completed projects by the end of 2017 and 33 closed projects. We can also evaluate the result achieved by the end of September 2018, when 18 investment projects were closed. The largest investment projects included SAM Automotive with an investment value of $€ 50$ million and 800 new jobs in the town of Velký Krtis, one of the least developed regions. Meanwhile, the second largest Mubea with an investment height of $€ 51$ million and 500 jobs will be realized in Kezmarok, which is also among the least developed districts. Both are implemented by German investors. (Report on SARIO's activities and the fulfillment of the strategic objectives for I., II., III. Q 2018) 
Table 4. Development of the numbers of semifinished investment projects

\begin{tabular}{|l|l|c|c|c|c|c|}
\hline \multicolumn{2}{|l|}{} & 2013 & 2014 & 2015 & 2016 & 2017 \\
\hline \multicolumn{2}{|l|}{ number of semifinished projects } & 50 & 44 & 60 & 66 & 76 \\
\hline \multirow{3}{*}{ impact of semifinished projects } & the amount of the & $\begin{array}{c}€ 1,300 \\
\text { million }\end{array}$ & $\begin{array}{c}€ 1,740 \\
\text { million }\end{array}$ & $\begin{array}{c}€ 2,200 \\
\text { million }\end{array}$ & $\begin{array}{c}€ 1,800 \\
\text { million }\end{array}$ & $\begin{array}{c}€ 4,200 \\
\text { million }\end{array}$ \\
\cline { 2 - 7 } & investment & 11,500 & 16,000 & 16,000 & 23,800 & 31,000 \\
\hline
\end{tabular}

Source: Annual report SARIO 2017

Another means of encouraging investors to invest in Slovakia is foreign travel. During 2017, SARIO Investment Projects employees participated in 23 investment-focused foreign business trips. The primary purpose of investment foreign business routes was to highlight Slovakia as an attractive investment destination in the region of Central and Eastern Europe and to disseminate Good Idea Slovakia messages. This goal has been successful in fulfilling the Agency in 2017, indicating both an increase in public interest in content published on SARIO social networks and an increase in new registered projects and opportunities.

In 2017 the Agency SARIO participated in a relatively high number of investment events in the United Kingdom (5 events). Besides the possibility of presenting Slovakia and the possibility to capture the investment signals of companies considering relocations, this also represented an opportunity to understand and gain know-how as companies and their management in the UK are thinking about Brexit and their business. Several hundred high-profile representatives of the private as well as the public sphere participated cumulatively in the events, creating the basis for acquiring new contacts and identifying investment signals from foreign companies and further targeting potential investors or partners.

\subsection{Foreign trade and internationalization of small and medium-sized enterprises}

SARIO provides its free services to internationalize Slovak companies ready to export their products and services regardless of their location. Supporting activities towards fast-growing markets concentrated mainly in Southeast Asia (China, Vietnam), Near East (Iran, Oman) and Latin America (Cuba, Mexico) and in Belarus, Russian Federation and Kazakhstan. Emphasis was placed on these sectors - power engineering, mechanical engineering, production automation, agricultural technology, water technology.

Several events, including business missions to more developed countries, accompanying visits to Peter Pellegrini, Vice-President of the Government for Investments and Informatisation of the Slovak Republic, were prepared to support the export of services. Mission participants represented the IT and communication technology sectors (namely cybernetic and information security, data mining, big data, e-gov solutions). But also the health and pharmaceutical sectors and high-tech companies. With the Office of the Vice-President of the Government for Investment and Informatisation, the Agency has been involved in the organization of missions to Israel, Iran, Finland and Estonia, Oman, Vietnam, Mongolia and China.

In the year 2017, the employees of the Foreign Trade Department participated in 64 events - missions of Slovak businessmen abroad, missions and co-operation events of foreign entrepreneurs in Slovakia, organization of Slovak stalls at major international trade fairs. Organization of business missions enjoys high popularity between businessmen as well as state representatives. In 2017 they organized 15 missions abroad and accepted 10 foreign delegations in the Slovak Republic. Due to the high interest of entrepreneurs, there was a sophisticated system of judging and selecting entrepreneurs for individual missions.

SARIO ensures participation in the most important world events. On 19-23 june 2017 a business mission was held at EXPO 2017 in Astany under the auspices of the Ministry of Agriculture and Rural Development of the SR and the Ministry of Education, Science, Research and Sport of the Slovak Republic, organized by SARIO in cooperation with the Ministry of Economy of the Slovak Republic. On the grounds of the Slovak Pavilion, 29 participating companies offered space for their presentation and bilateral negotiations with the agreed partners. A total of 287 registered meetings (B2B) were held with 117 foreign companies. 
At the same time, on a professional level, it provides business trips for top government officials. As an example, we can mention the following event. On 20-24 November 2017 accompanied by Andrey Kiska, President of the SR, also attended a 12-member Business and Academic Delegation on his official visit to Mexico. On Wednesday, November 22, 2017, the business forum 'Innovative Economies of the 21st Century' took place in Mexico City, during which SARIO signed a Memorandum of Understanding with ProMéxico. The Forum was attended by the President of the Slovak Republic, Minister of Economy MX, Chairman of COMCE, as well as representatives ProMexico, AMEXCID.

For more than 11 years, the flagship of B2B events to support the export performance of Slovak companies has been the Slovak Cooperative Exchange. It is the largest international event in Slovakia organized by SARIO since 2007. Throughout its history, the Slovak Cooperative Exchange has been able to combine business and production potential with 2,101 firms from 38 countries, 4,993 participants, 1,226 Slovak and 884 foreign companies. Since its inception have taken place 5,080 official pre-planned B2B negotiations.

The objective of the event is to provide participants with the unique opportunity to negotiate with relevant business partners on a single day and place, space and platform to present subcontracting offerings, tenders, free production capacities, joint venture requirements with foreign partners, and investment opportunities in selected sectors. The business program represents B2B negotiations according to predefined schedules. The accompanying program consists of a moderated professional conference, workshops, signature of memorands and international cooperation agreements. The overview of Slovak Cooperative Exchange activities since 2007 is shown in Table 5.

Table 5. An overview of the events of the Slovak Contracts Exchange in the years 2007 to 2017

\begin{tabular}{|c|c|c|c|c|c|}
\hline Volume & Year & Place & $\begin{array}{l}\text { Number of } \\
\text { enterprises }\end{array}$ & Partner country / focus & Charge \\
\hline 1 & 2007 & Trencin (SK) & 113 & - & - \\
\hline 2 & 2008 & Banska Bystrica (SK) & 240 & Czech Republic & Ministry of economy of the SR \\
\hline 3 & 2009 & Presov $(\mathrm{SK})$ & 249 & Russia & Ministry of economy of the SR \\
\hline 4 & 2010 & Nitra (SK) & 120 & France & Ministry of economy of the SR \\
\hline 5 & 2011 & Zilina (SK) & 139 & Serbia & Ministry of economy of the SR \\
\hline 6 & 2012 & Nitra (SK) & 86 & Bulgaria & Ministry of economy of the SR \\
\hline 7 & 2013 & Bratislava (SK) & 261 & Russia & Ministry of economy of the SR \\
\hline 8 & 2014 & Bratislava (SK) & 149 & V4 countries, Austria & Ministry of economy of the SR \\
\hline 9 & 2015 & Bratislava (SK) & 205 & China & Ministry of economy of the SR \\
\hline 10 & 2016 & Bratislava (SK) & 263 & Automotive & Ministry of economy of the SR \\
\hline 11 & 2017 & Nitra & 84 & Engineering industry & Ministry of economy of the SR \\
\hline 12 & 2017 & Bratislava (SK) & 123 & Smart industry & Ministry of economy of the SR \\
\hline 13 & 2017 & Kosice (SK) & 281 & Medley sectors & Ministry of economy of the SR \\
\hline
\end{tabular}

Source: Annual report SARIO 2017

\subsection{Increasing the expertise of entrepreneurs and exporters in the field of investment and foreign trade}

The SARIO Agency also contributes to the building of entrepreneurship expertise, primarily by organizing educational, professional and educational seminars on various topics. These cover either specific territories or foreign trade techniques, support the building of an entrepreneurial environment or otherwise reflect the interests of entrepreneurs. Seminars had several formats in 2017, in the first half of the year, the SARIO Proexport Academy cycle and the SARIO Business Breakfast cycle. In addition, the Agency organizes further ad hoc conferences and seminars, together with 23 participants with nearly 400 participants in 2017. It has continued to work actively with the Business Services Forum, which has been established and operates on the 
American Chamber of Commerce platform and brings together 28 members with a strategic services division or an outsourcing service segment in the Slovak Republic. The essence of outsourcing is the displacement or separation of certain corporate activities from the enterprise and their securing to another firm - an external provider. The Investment Projects Department is engaged in a long-term presentation of legislative standards in the area of investment aid. In the first place, it is Law no. 57 of 2018 on regional investment aid. This Act regulates the provision of regional investment aid. What are the rights and obligations of the recipient of investment aid and the competence of the state administration bodies in providing investment aid and controlling its use. An important part of this law is which investment aid it provides and who is the recipient of this assistance. Furthermore, it is Government Regulation no. 195 of 2018 for the provision of investment aid, which entered into force on 1 July 2018. This Regulation provides information on the form of investment aid. It is very important to know the conditions for providing investment aid. What must be the minimum investment amount and the number of newly created jobs. SARIO spatially developed the categorization of the Slovakian districts based on the unemployment rate from which the investment aid is based. The categorization of the regions of Slovakia and the conditions for the provision of investment aid are shown in Figure 1 and Table 6.

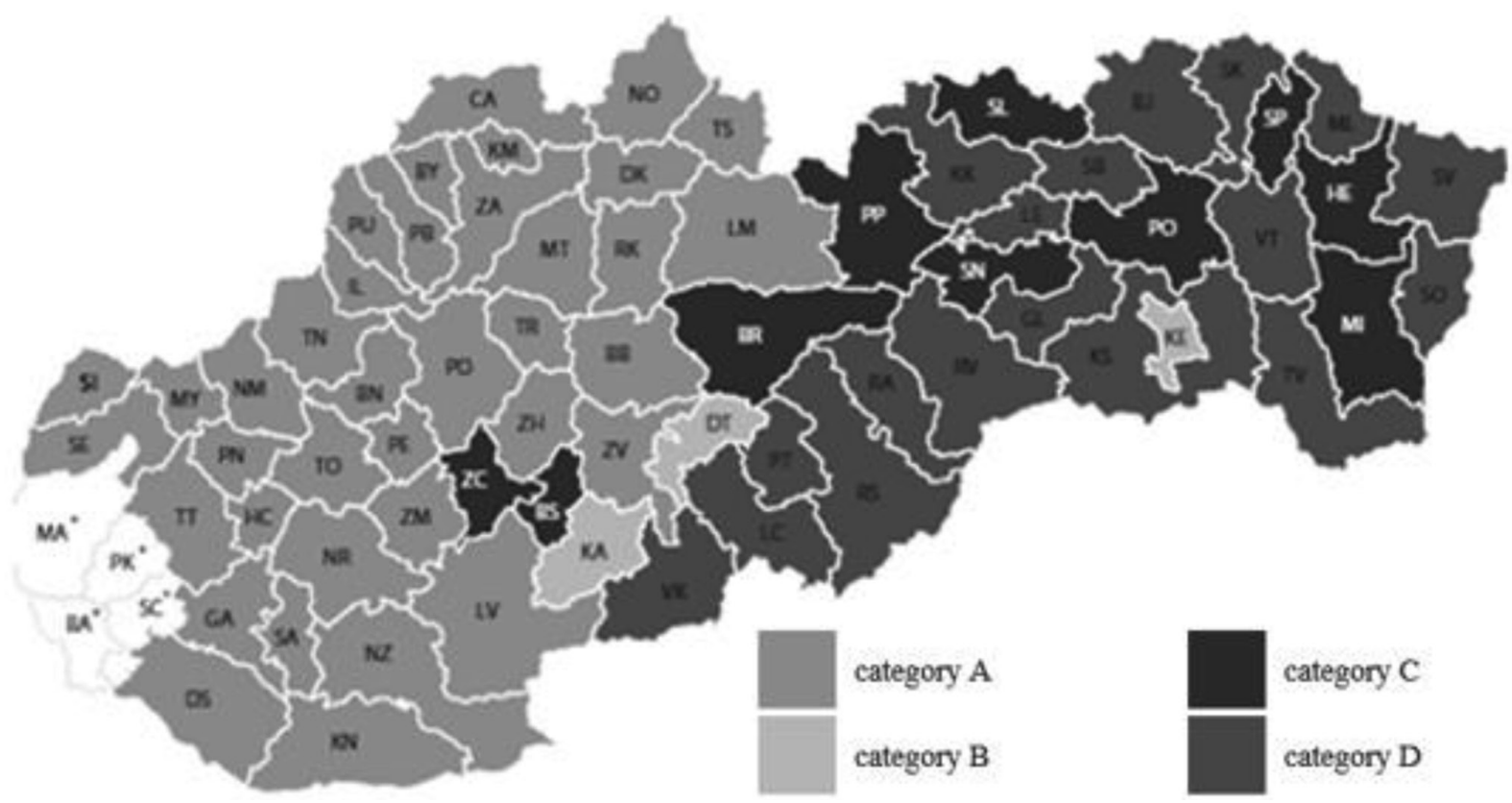

Figure 1. Categorization of Slovakian regions based on the unemployment rate

Source: Investment aid in Slovakia - information brochure SARIO 2018

Note: * in the region of Bratislava it is not possible to provide investment aid

Table 6. Overview of investment aid valid from 1 july 2018

\begin{tabular}{|c|c|c|c|c|c|}
\hline \multirow{2}{*}{ Category } & $\begin{array}{c}\text { A minimum share } \\
\text { of new technology } \\
\text { for investment }\end{array}$ & $\begin{array}{c}\text { Minimum } \\
\text { subvention } \\
\text { amount }\end{array}$ & $\begin{array}{c}\text { Minimum } \\
\text { subvention } \\
\text { amount }\end{array}$ & $\begin{array}{c}\text { Minimum amount } \\
\text { of subvention / the } \\
\text { number of new jobs }\end{array}$ & $\begin{array}{c}\text { Minimum } \\
\text { subvention } \\
\text { amount }\end{array}$ \\
\cline { 3 - 7 } & $60 \%$ & Subvention & $\begin{array}{c}\text { Reduction of } \\
\text { income tax }\end{array}$ & $\begin{array}{c}\text { Financial aid for } \\
\text { newly created jobs }\end{array}$ & $\begin{array}{c}\text { Sale of real estate } \\
\text { at a favored price }\end{array}$ \\
\hline $\mathrm{A}$ & $50 \%$ & $€ 30$ million & $€ 3$ million & $€ 3$ million $/ 200$ & $€ 3$ million \\
\hline $\mathrm{B}$ & $40 \%$ & $€ 20$ million & $€ 1,5$ million & $€ 1,5$ million $/ 100$ & $€ 1,5$ million \\
\hline $\mathrm{C}$ & $30 \%$ & $€ 1$ million & $€ 0,2$ million & $€ 0,2$ million $/ 20$ & $€ 0,2$ million \\
\hline $\mathrm{D}$ & & & & &
\end{tabular}

Source: Investment aid in Slovakia - information brochure SARIO 2018 
If the aid recipient is a small and medium-sized enterprise, the minimum investment amount and the number of newly created jobs are reduced to at least 1/2. The minimum amount of investment in the case of grant applications varies from one district to another by virtue of its membership of the priority area of the sectoral specialization. (Investment aid in Slovakia - information brochure SARIO 2018)

\section{Conclusion}

If we looked well at the categorization of the districts and the overview of the investment aid, we could draw a conclusion as to the development in Slovakia. At the beginning of its inception, foreign investments created the conditions for the establishment of a European assembly plant. If we move to the present, there is a significant shift. Investments from foreign and domestic investors with high added value are the basis. This trend has to be very reactive to the state by accelerating the completion of an adequate infrastructure, which will increase the interest in investing in Slovakia.

\section{References}

Act no. 57/2018 on regional investment aid

Alfaro, L.; Johnson, M.S. 2013. Foreign Direct Investment and Growth, The Evidence and Impact of Financial Globalization: 299 - 309. ISBN 9780123978745. https://doi.org/10.1016/B978-0-12-397874-5.00016-6

Andrejovská, A.; Hudáková, M. 2016. Classification of EU countries in the context of corporate income tax, Acta Universitatis Agriculturae et Silviculturae Mendelianae Brunensis, 64 (5): 1699-1708. https://doi.org/10.11118/actaun201664051699

Annual report SARIO 2017

Azman-Saini, W.N.W.; Baharumshah, A.Z.; Law, S. H. 2010. Foreign direct investment, economic freedom and economic growth: international evidence, Economic Modelling, 27 (5): 1079-1089. https://doi.org/10.1016/j.econmod.2010.04.001

Baláž, P. et al. 2001. International Business. Bratislava: Sprit. ISBN 88-88848-68-7

Batkovskiy, A.M., Leonov, A.V., Pronin, A.Yu ., Semenova, E.G., Fomina, A.V., Balashov, V.M. 2019. Sustainable development of Industry 4.0: the case of high-tech products system design, Entrepreneurship and Sustainability Issues 6(4): 1823-1838. http://doi. org/10.9770/jesi.2019.6.4(20)

Bénassy-Quéré, A.; Coupet, M.; Mayer, T. 2007. Institutional determinants of foreign direct investment, World Economy, 30(5): 764782. https://doi.org/10.1111/j.1467-9701.2007.01022.x

Beresecká, J.; Kapusniak, J. 2014. Safety and corporative communications in rural accommodation facilities located in rural areas, Advanced Materials Research, 1001: 526-533. https://doi.org/10.4028/www.scientific.net/AMR.1001.526

Bevan, A.A.; Estrin, S. 2004. The determinants of foreign direct investment into European transition economies, Journal of Comparative Economics, 32(4): 775-787. https://doi.org/10.1016/j.jce.2004.08.006

Borensztein, E.; De Gregorio, J.; Lee, J.-W. 1998. How does foreign direct investment affect economic growth?, Journal of International Economics, 45(1): 115-135. https://doi.org/10.1016/S0022-1996(97)00033-0

Bujdosó, Z.; Kovács, T.; Csaba, S.; Brambauer, Z. 2016. "New” direction of urban development from a central European perspective, Theoretical and Empirical Researches in Urban Management, 11(2), pp. 54-63. http://um.ase.ro/no112/4.pdf

Eddelani, O.; El Idrissi, N. E.; Monni, S. 2019. Territorialized forms of production in Morocco: provisional assessment for an own model in gestation, Insights into Regional Development 1(1): 6-18. https://doi.org/10.9770/ird.2019.1.1(1)

Fabus, M. 2014. Foreign direct investment and its impact on the Slovak Republic's economy, Economic Annals-XXI, Part 1 9-10: 42-45. http://soskin.info/userfiles/file/2014/9-10_2014/1/Fabus.pdf

Fabus, M. 2015. Impact of foreign direct investment on unemployment development in selected regions of Slovak Republic, Economic Annals-XXI, 155(11-12): 63-66. http://soskin.info/userfiles/file/Economic-Annals-pdf/S155-0014(14)063.pdf

Filip, S.; Filipová, L.; Sehlíková, B. 2019. Croo-border Cooperation in the Development of Tourism of the Slovak Republic. Bratislava Wolters Kluwer. p. 210. ISBN 978-80-571-0014-0. 
Gecikova, I.; Papcunova, V.; Belajova, A. 2014. The quality measurement of management in local self-government in the Slovak Republic, Economic Annals-XXI, Part 1 9-10: 38-41 http://soskin.info/userfiles/file/2014/9-10_2014/1/Gecikova,Papcunova,Belajova. pdf

Ghazalian, P.L.; Amponsem, F. 2019. The effects of economic freedom on FDI inflows: an empirical analysis, Applied Economics 51(11): 1111-1132

Giedraitis, A.; Stašys, R.; Skirpstaitė, R. 2017. Management team development opportunities: a case of Lithuanian furniture company, Entrepreneurship and Sustainability Issues, 5(2): 212-222. https://doi.org/10.9770/jesi.2017.5.2(4)

Government Program Statement for 2012 - 2016

Government Program Statement for 2016 - 2020

Government Regulation no. 195/2018 on investment aid

Investment aid in Slovakia - information brochure SARIO 2018

Kais, S. 2018. Foreign Direct Investment, Financial Development and Their Impact on the GDP Growth in Low-income Countries, International Economic Journal, 32(3): 483-497 https://doi.org/10.1080/10168737.2018.1529813

Lialina, A. 2019. Labor market security in the light of external labor migration: new theoretical findings, Entrepreneurship and Sustainability Issues 6(3): 1105-1125. http://doi.org/10.9770/jesi.2019.6.3(11)

Lipková, L'. et al. 2012. International Economic Relations. Bratislava: Sprit. ISBN 80-89085-55-5

Mayorova, A.N., Panasenko, S.V., Nikishin, A.F., Ivanov, G.G., Mayorova, E.A. 2018. Analyzing regional differences in the condition and development of trade in Russia, Entrepreneurship and Sustainability Issues, 6(2): 927-938. http://doi.org/10.9770/jesi.2018.6.2(30)

Melnyk, T.; Oksana, L. 2018. Economic effects of dynamics in migration processes, MEST Journal (MESTE), 6(1): 68-78. https://doi.org/10.12709/mest.06.06.01.0

Panfiluk, E.; Szymańska, E. 2017. The measurement of the innovativeness of health tourism services using an adequacy matrix title of the article, Entrepreneurship and Sustainability Issues, 4(4): 400-420. http://doi.org/10.9770/jesi.2017.4.4(1)

Pavolová, H.; Bakalár, T.; Emhemed, E.M.A, Hajduová, Z.; Pafčo, M. 2019. Model of sustainable regional development with implementation of brownfield areas, Entrepreneurship and Sustainability Issues 6(3): 1088-1100. http://doi.org/10.9770/jesi.2019.6.3(2)

Petrenko, Y.; Vechkinzova, E.; Antonov, V. 2019. Transition from the industrial clusters to the smart specialization of the regions in Kazakhstan, Insights into Regional Development 1(2): 118-128. https://doi.org/10.9770/ird.2019.1.2(3)

Report on SARIO's activities and the fulfillment of the strategic objectives for I., II., III. Q 2018

Sajid, A.; Lan, P. N. 2010. Foreign direct investment and economic growth in Vietnam, Asia Pacific Business Review, 16:1-2: 183202. https://doi.org/10.1080/10438590802511031

Siller, H.; Cibák, L. 2016. Korruption und ihre gesamtwirtschaftliche Bedeutung, Kriminalistik, ISSN 0023-4699, 70(1), 50-55.

Shuyan, L., Fabuš, M. 2019. Study on the spatial distribution of China's Outward Foreign Direct Investment in EU and its influencing factors, Entrepreneurship and Sustainability Issues, 6(3), 1080-1096. http://doi.org/10.9770/jesi.2019.6.3(16)

Tvaronavičienè, M., Černevičiūtè, J. 2015. Technology transfer phenomenon and its impact on sustainable development, Journal of Security and Sustainability Issues, 5(1): 87-97. http://dx.doi.org/10.9770/jssi.2015.5.1(7)

Vaysilova E. 2016. Optimization of the financial result by method "price elasticity of sales, International scientific conference "MENAGEMENT 2016", Belgrade, Serbia, 5-6 May, 2016, p. 284, ISBN 978-86-6375-053-1

Zeibote, Z.; Volkova, T.; Todorov, K. 2019. The impact of globalization on regional development and competitiveness: cases of selected regions, Insights into Regional Development 1(1): 33-47. https://doi.org/10.9770/ird.2019.1.1(3) 


\section{Aknowledgements}

This paper was supported by the project, which has received funding from the Grant Research Agency of the School of Economics and Management in Public Administration in Bratislava, of the Slovak Republic.

František VOJTECH is an associate professor at the School of Economics and Management in Public Administration in Bratislava. He graduated from the Military High School in Management (1978). In 2004 he received a PhD degree at the Faculty of Management at Comenius University in Bratislava. In 2018 he was awarded the title of Associate Professor at the same school. For more than 30 years he has been involved in various management and control functions in the state administration, and he is also teaching the Regional Policy of the European Union, the Strategy of Socio-Economic Development

ORCID ID: https://orcid.org/0000-0003-3099-0108

Michal LEVICKÝ is a university lecturer and researcher at the University of Constantine the Philosopher in Nitra. He graduated from the Faculty of Economics and Management of the Slovak Agricultural University in Nitra (2010). In 2013 he received a PhD degree at the same school in the field of cross-cutting and sectoral economics. Currently he teaches disciplines Financial Analysis of Business, Business Economics, Finance and Banking, and National Economy Policy.

ORCID ID: https://orcid.org/0000-0002-5297-1664

Stanislav FILIP, Assoc prof. Ing. PhD. is the Vice-Rector for foreign affairs an teacher of the School of Economics and management in Public Administration in Bratislava. His text books, monographs and scientific papers deal with the Risk and crisis managemtn in public sector, international crisis management and public administration at the national and EU level. He is succesfull leader and manager of the several scientific projects with support from the EU structural funds. He also organise and control international colaboration and Erasmus plus program with the high educational and research institutions in abroad.

Researcher ID: F-7984-2017

ORCID ID: https://orcid.org/0000-0003-3000-9383

This work is licensed under the Creative Commons Attribution International License (CC BY).

http://creativecommons.org/licenses/by/4.0/ 